\title{
Early Seizures After Stroke: Neurology Intensive Care Unit Experience
} İnme Sonrası Erken Başlangıçlı Nöbetler: Nöroloji Yoğun Bakım Ünitesi Deneyimi

\author{
(D Şadiye Gümüşyayla, ( Gönül Vural \\ Ankara Yildirim Beyazit University Faculty of Medicine, Department of Neurology, Ankara, Turkey
}

\begin{abstract}
Objective: The aim of this study was to investigate the frequency of early seizures, the affecting factors, and the prognostic effect of seizures in patients with acute ischemic stroke (AIS), intracerebral hemorrhage (ICH), and sinus venous thrombosis (SVT) examined in the intensive care unit (ICU).

Materials and Methods: In the neurology ICU, the records of patients followed up with AIS, ICH, and SVT within a defined time period were retrospectively examined.

Results: Early seizures occurred in 48 out of 199 patients who were followed up with AIS, ICH, and SVT in the neurology ICU within the specified time period. The frequency of having early seizures was found to be higher in patients with left hemisphere lesions, cortical lesions, and those with AIS with hemorrhagic transformation. Lesion volume was found to be higher in patients with AIS who had early seizures compared with those who had AIS without seizures. Early seizures were observed in all patients with SVT who were followed up in the ICU.

Conclusion: Early seizures are a common complication in patients with stroke followed up in neurology ICUs. Determination of effective factors in early seizures is important for its early diagnosis and treatment.
\end{abstract}

Keywords: Early seizure, stroke, neurological intensive care unit

$\ddot{\mathbf{O} z}$

Amaç: Bu çalışmanın amacı akut iskemik inme (AİI), intraserebral hemoraji (İSH) ve sinüs ven trombozu (SVT) nedeni ile yoğun bakım ünitesinde (YBÜ) takip edilen hastalarda erken başlangıçlı nöbet geçirme sıklığını, bunda etkili faktörleri ve nöbetin prognoza etkisini araştırmaktır.

Gereç ve Yöntem: Nöroloji YBÜ’de, belirlenen zaman dilimi içerisinde AİI, İSH ve SVT tanısı ile takip edilen hasta kayıtları retrospektif olarak incelenmiştir. Bulgular: Belirlenen zaman dilimi içerinde nöroloji YBÜ'de AİI, İSH ve SVT tanısı ile takip edilen 199 hastadan 48'inde erken başlangıçlı nöbet ortaya çıkmıştır. erken başlangıçlı nöbet geçirme sıklığ1 sol hemisfer lezyonu, kortikal lezyon ve hemorajik transformasyonu olan AİI’li hastalarda daha yüksek bulunmuştur. erken başlangıçlı nöbet geçiren AIİ'li hastalarda lezyon volümü nöbeti olmayan AIİ'li hastalara göre yüksek bulunmuştur. YBÜ’de takip edilen SVT’li bireylerin tamamında erken başlangıçlı nöbet gözlemlenmiştir.

Sonuç: Nöroloji YBÜ’de takip edilen inme hastalarında erken başlangıçlı nöbet sık görülen bir komplikasyondur. Erken başlangıçlı nöbetde etkili faktörlerin tespiti erken tanı ve tedavi için önemlidir.

Anahtar Kelimeler: Erken başlangıçlı nöbet, inme, nöroloji yoğun bakım ünitesi

\section{Introduction}

Stroke is defined by the World Health Organization as a clinical syndrome characterized by the rapid onset of signs and symptoms of loss of focal cerebral function due to vascular causes (1). Strokes were divided into three main groups as cerebral ischemia (60-80\%), intracerebral hemorrhage (ICH) (10-15\%), and subarachnoid hemorrhage (SAH) (3-10\%) based on neuroradiologic, cardiologic, hematologic, and biochemical examinations (2). Sinus venous thrombosis (SVT), which is responsible for approximately $1 \%$ of all strokes, is a neurologic emergency situation characterized by thrombosis of the intracranial cerebral sinuses and/or cerebral venous pathways leading to venous drainage retention, intracranial pressure elevation, and/or venous infarctions (3).

Seizures are well-known and serious complications of stroke $(4,5,6)$. Post-stroke seizures can be divided into two groups

\footnotetext{
Address for Correspondence/Yazışma Adresi: Şadiye Gümüşyayla MD, Ankara Yildirim Beyazit University Faculty of Medicine, Department of Neurology, Ankara, Turkey

Phone: +90 5062820234 E-mail: sadiyetemel@yahoo.com ORCID ID: orcid.org/0000-0002-2279-2016

Received/Geliş Tarihi: 19.06.2017 Accepted/Kabul Tarihi: 25.08.2017

${ }^{\circ}$ Copyright 2018 by Turkish Neurological Society

Turkish Journal of Neurology published by Galenos Publishing House.
} 
as early- and late-onset seizures according to the temporal relationship between the time of stroke and seizure. Early seizures are classified as seizures within 15 days after stroke, whereas late seizures are classified as seizures starting 16 days after stroke (7). The incidence of early or late seizures after acute ischemic stroke (AIS) has been reported in a wide range (2-67\%). This ratio is between $8-15 \%$ after $\mathrm{ICH}$ and $\mathrm{SAH}(8,9,10)$. It reaches a high figure of $44 \%$ in SVT (11). The observation of early seizures in particular after stroke has been linked to many factors including type, location, size, and severity of stroke $(5,6)$.

In this study, we investigated the frequency of early seizure development and factors affecting seizure development, the effect of seizure on disease prognosis, and its response to antiepileptic treatment in patients followed up with AIS, ICH, and SVT in the neurology intensive care unit (ICU).

\section{Materials and Methods}

One hundred ninety-nine patients who were followed up with AIS, ICH, and SVT diagnoses in the neurological ICU between January 2012 and July 2016 and met the specified inclusion criteria were included in the study. Demographic, clinical, biochemical, and neuroradiologic data of patients were obtained by investigating patient files retrospectively. Post-stroke early seizure was defined as a seizure within the first 15 days after stroke. Patients were divided into two groups as patients with and without early seizure. In the group of patients with early seizure, those with infection, metabolic disorder, and electrolyte imbalance, and drug and alcohol users were excluded from the study. Patients who had previously had epileptic seizures or were under suspicion of having seizures were excluded from both groups. Patients aged younger than 18 years with SAH, and subdural and epidural hemorrhage were excluded from the study. Clinical characteristics, radiologic findings, treatments, mean duration of hospitalization, and onsettime of seizure were recorded for each patient. Stroke types in patients were identified by considering the clinical features and neuroradiologic findings of the patients. National Institutes of Health Stroke Scale (NIHSS) scores and modified Rankin Score (mRS) were calculated from the referral neurologic examinations of patients with AIS and ICH. The information in the patient files was used to calculate the mRS three months after admission to the hospital. Patients with SVT were assessed on the basis of the functional status Barthel index (BI): poor recovery (BI 12), partial recovery (BI 13-19), and complete recovery (BI 20). Lesion volumes were calculated using diffusion-weighted magnetic resonance images (MRI) and brain computed tomography images performed within the first 24 hours after stroke during admission for patients with AIS and ICH, respectively. When lesion volumes were calculated, the relevant regions were measured by marking the circumference of the lesion area for each incision. SVT diagnosis was confirmed by using cranial MRI and MRI venography in all patients diagnosed with SVT.

\section{Statistical Analysis}

Number and percentage distributions were given to variables used in the study and categorical variables such as sex, presence of seizure, type of disease, initial symptom, lesion side, presence of status epilepticus, the number of anti-epileptic drugs (AED), presence of hemorrhagic infarcts, type of AED, lesion size, response to treatment, and presence of cortical lesion. The mean, standard deviation, minimum and maximum values of the age, length of hospitalization, epileptic seizure duration, $\mathrm{mRS}$ at admission, $\mathrm{mRS}$ 3 months after admission, NIHSS at admission, and lesion volume variables are given. The normal distribution of continuous variables included in the study was evaluated using the Shapiro-Wilk test. Nonparametric tests were applied to variables that were not normally distributed and the median and interquartile range values are given in addition to the descriptive statistics. The lesion side, presence of cortical lesion, presence of status epilepticus, hemorrhagic infarct, and AED number on the basis of early seizures presence was statistically differentiated using the Chi-square comparison test. Likewise, the effect of status epilepticus on the lesion side in patients with seizures was analyzed using the Chi-square comparison test. The Mann-Whitney U non-parametric test was used to determine whether there was a statistically significant difference in lesion volume in terms of the presence of status epilepticus in patients with early seizures. Similarly, the Mann-Whitney U nonparametric test was used to determine whether the age, lesion volume, seizure duration, and length of stay of the individuals with early seizures were statistically significant. The chi-square comparison test was used to determine whether disease types differed statistically in terms of having early seizures. The Kruskal-Wallis nonparametric test was employed to analyze whether there was a statistically significant difference between seizure duration and lesion volume in the case of stroke type. The Mann-Whitney U non-parametric test was used to determine whether the NIHSS, lesion volume, mRS on referral, and mRS in the third month were statistically significantly different in individuals with AIS and ICH (separately) in terms of the presence of seizure. The IBM SPSS Statistics package 21.0 (IBM Corp. released 2012. IBM SPSS Statistics for Windows, Version 21.0, Armonk, NY: IBM Corp.) and MS-Excel 2007 were used for statistical analysis and calculations. The level of statistical significance was accepted as $\mathrm{p}<0.05$.

\section{Results}

The demographic information of patients included in the study is given in Table 1 .

\begin{tabular}{|lc|}
\hline Table 1. Demographic information & \\
Semographic information & $\begin{array}{c}\text { Number } \\
\text { (percentage); } \mathbf{n}(\%)\end{array}$ \\
Female & $111(55.8)$ \\
Male & $88(44.2)$ \\
Seizure & \\
Present & $48(24.1)$ \\
Absent & $151(75.9)$ \\
Stroke type & $149(74.9)$ \\
Acute ischemic stroke & $39(19.6)$ \\
Intracerebral hemorrhage & $11(5.5)$ \\
Sinus venous thrombosis & \\
\hline
\end{tabular}




\begin{tabular}{|lc|}
\hline Table 1. Continued & \\
Demographic information & Number \\
(percentage); $\mathbf{n}(\%)$
\end{tabular}

It was found that there was no statistically significant difference between sex and having early seizures ( $p=0.282)$. Among individuals who had early seizures, right-sided lesions were found in $29.2 \%$, left-sided lesions in $56.2 \%$, bilateral lesions in $8.4 \%$, and the intraventricular lesions in $6.2 \%$. Among individuals who had no early seizures, $51.6 \%$ had right-sided lesions, $47.0 \%$ had left-sided lesions, and the remainder had bilateral and intraventricular lesions. The lesion sides showed a statistically significant difference according to the presence of early seizure $(\mathrm{p}<0.001)$. The lesion side of the majority of individuals with early seizures was found as the left side, the majority of individuals with no seizures had right-sided lesion. The number of patients with early seizures and cortical lesions was calculated as 27 , and the number of patients with early seizures without cortical lesions was 20. Most patients who had no early seizures had no cortical lesions. There was a statistically significant relationship between the presence of cortical lesions and individuals having early seizures $(\mathrm{p}=0.001)$. Most individuals with early seizures had cortical lesions, and the majority of individuals with no seizures had no cortical lesions.

Of the individuals who had early seizures, $77.1 \%$ had status epilepticus; $59.45 \%$ of the patients with status epilepticus were female, and $40.55 \%$ were male. The mean age of the patients with status epilepticus was $64 \pm 20.21$ and the mean duration of hospitalization was $33.21 \pm 48.91$ days. Of these patients, 62\% were followed by AIS, $21.62 \%$ by ICH, and $16.22 \%$ by SVT. The lesion side was right in $27.03 \%$ of patients with status epilepticus, left in $54.05 \%$, bilateral in $10.81 \%$, and intraventricular in $8.11 \%$; $16.22 \%$ of these patients had hemorrhagic infarction, $83.78 \%$ had no hemorrhagic infarction, $54.05 \%$ had cortical lesions, and $45.95 \%$ no cortical lesions. Seizure type was generalized in $86.49 \%$ and $13.54 \%$ had focal seizures.

Among the patients who had early seizures, eight had hemorrhagic infarction and 40 had none. In contrast, among the patients who had no early seizures, 8 had hemorrhagic infarction and 114 had none. The presence or absence of hemorrhagic infarction based on having early seizure was statistically significant $(\mathrm{p}=0.042)$. The majority of individuals who had early seizures had no hemorrhagic infarction. Forty patients with early seizures had only one AED and 8 had more than one AED (Table 2).

The mean age of the patients who had early seizures was $67.06 \pm 19.42$ years, and the mean age of those who had no seizures was $73.76 \pm 12.16$ years. The mean age of patients showed no statistically significant difference in terms of the presence of early seizures $(\mathrm{p}=0.076)$. The mean hospitalization duration of patients who had early seizures was determined as $28.66 \pm 43.84$ days and that of patients who had no seizures was $34.32 \pm 43.49$ days. There was no statistically significant difference in the length of hospitalization for patients in terms of presence or absence of early seizures $(\mathrm{p}=0.486)$. The mean seizure duration of patients who had early seizures was calculated as $2.04 \pm 2.57$ day. The mean lesion volume was calculated as $90.50 \pm 96.45 \mathrm{~cm}^{3}$ for the patients who had early seizures, and the mean lesion volume for those with no seizures was $69.79 \pm 104.72 \mathrm{~cm}^{3}$. There was a statistically significant difference in lesion volume values between patients with and without early seizures $(\mathrm{p}=0.033)$. The lesion volumes of patients with early seizures were higher compared with those without seizure (Table 3).

Eight patients with AIS had early seizures and 120 had no early seizures, 8 of the patients with $\mathrm{ICH}$ had early seizures and 31 had no early seizures, and 11 patients with SVT (all those with SVT) had early seizures (Table 4). The mean duration of seizure for individuals with AIS was $2.55 \pm 2.84$ days, the mean duration of seizure for those with ICH was $2.12 \pm 2.41$ days, and the mean duration of seizure for patients with SVT was $0.63 \pm 1.20$ days. There was no statistically significant difference in seizure duration 
Table 2. Comparison of sex, lesion side, presence of cortical lesion, presence of status epilepticus, and presence of hemorrhagic infarct based on early seizure

Early seizure

\begin{tabular}{lcccc} 
Variables & $\begin{array}{c}\text { Present } \mathrm{n} \\
(\%)\end{array}$ & $\begin{array}{c}\text { Absent } \mathrm{n} \\
(\%)\end{array}$ & $\chi 2$ & $\mathrm{p}$ \\
Sex & & & & \\
$\quad$ Female & $30(62.5)$ & $81(53.6)$ & 1.159 & 0.282 \\
Male & $18(37.5)$ & $70(46.4)$ & & \\
Lesion side & & & & \\
$\quad$ Right & $14(29.2)$ & $78(51.6)$ & & \\
Left & $27(56.2)$ & $71(47.0)$ & 18.802 & $<0.001$ \\
$\quad$ Bilateral & $4(8.4)$ & $1(0.7)$ & & \\
Intraventricular & $3(6.2)$ & $1(0.7)$ & & \\
Cortical lesion & & & & \\
Present & $27(57.4)$ & $46(30.5)$ & 11.212 & 0.001 \\
Absent & $20(42.6)$ & $105(69.5)$ & & \\
Status epilepticus & & & & \\
Present & $37(77.1)$ & - & & \\
Absent & $11(22.9)$ & - & & \\
Hemorrhagic infarct & & & & \\
Present & $8(16.7)$ & $8(6.6)$ & & \\
Absent & $40(83.3)$ & $114(93.4)$ & & \\
Anti-epileptic drug number & & & \\
Monotherapy & $40(83.3)$ & - & & \\
Polytherapy & $8(16.7)$ & - & & \\
\hline
\end{tabular}

in terms of stroke type $(\mathrm{p}=0.094)$. The mean lesion volume for individuals with AIS and ICH was calculated as $80.26 \pm 111.32$ $\mathrm{cm}^{3}$ and $48.89 \pm 59.40 \mathrm{~cm}^{3}$, respectively. There was no statistically significant difference in lesion volumes in terms of stroke types $(\mathrm{p}=0.935)$.

The average NIHSS scores of individuals with AIS with and without early seizures were calculated as $17.89 \pm 9.10$ and 20.43 \pm 8.47 , respectively. The mean lesion volume for individuals with AIS who had early seizures was $102.60 \pm 104.89 \mathrm{~cm}^{3}$, and $75.24 \pm 112.52 \mathrm{~cm}^{3}$ for those without seizures. NIHSS values showed no statistically significant differences according to the presence of seizures $(\mathrm{p}=0.230)$. However, lesion volumes were statistically significantly different in terms of the presence of seizures $(p=0.034)$; the lesion volumes of patients with AIS who had early seizures were higher than those without seizures. The average NIHSS scores of patients with $\mathrm{ICH}$ who had early seizures were calculated as $22.75 \pm 8.56$, and $23.87 \pm 8.48$ for those without seizures. The mean lesion volume was determined as $49.65 \pm 43.02 \mathrm{~cm}^{3}$ for individuals with $\mathrm{ICH}$ who had early seizures, and $48.70 \pm 63.54 \mathrm{~cm}^{3}$ for those without seizures. There was no statistically significant difference between NIHSS and lesion volume values based on the presence of early seizures $(\mathrm{p}=0.848$, $\mathrm{p}=0.676$, respectively) (Table 5).

\section{Discussion}

In this study, we investigated the frequency of early seizure development and factors affecting seizure development, the effect of seizure on prognosis, and the response to antiepileptic treatment in patients with AIS, ICH, and SVT who were followed up in the neurology ICU. It was found that the presence of left hemispheric lesions, cortical lesions, presence of hemorrhagic infarct, and lesion size increased the frequency of having early seizures.

Table 3. Comparison of age, hospitalization time, seizure-onset time, and lesion volume based on early seizure

Early seizure

Test statistic

\begin{tabular}{|c|c|c|c|c|}
\hline Variables & $\begin{array}{c}\text { Presence } \\
\text { Mean } \pm \text { SD Median }(I Q R)\end{array}$ & $\begin{array}{c}\text { Absent } \\
\text { Mean } \pm \text { SD Median }(I Q R)\end{array}$ & $\mathrm{Z}$ & $\mathrm{p}$ \\
\hline Age & $\begin{array}{c}67.06 \pm 19.42 \\
72.50(27.00)\end{array}$ & $\begin{array}{c}73.76 \pm 12.16 \\
75.00(15.00)\end{array}$ & 1.772 & 0.076 \\
\hline Hospitalization time & $\begin{array}{c}28.66 \pm 43.84 \\
12.00(19.00)\end{array}$ & $\begin{array}{c}34.32 \pm 43.49 \\
18.00(35.00)\end{array}$ & 0.697 & 0.486 \\
\hline Seizure-onset time & $\begin{array}{c}2.04 \pm 2.57 \\
1.00(3.00)\end{array}$ & - & - & - \\
\hline Lesion volume & $\begin{array}{c}90.50 \pm 96.45 \\
60.51(129.25)\end{array}$ & $\begin{array}{l}69.79 \pm 104.72 \\
27.16(78.80)\end{array}$ & 2.131 & 0.033 \\
\hline
\end{tabular}

Table 4. Comparison of stroke type based on early seizures

\section{Variables}

Early seizure

Presence

Absent

AIS n (\%)

29 (19.5)

$120(80.5)$

\section{Stroke type}

ICH n (\%)

8 (20.5)

31 (79.5)
CVT n (\%)

11 (100.0)

$0(0.0)$
Test statistic $\mathrm{p}$

36.647
$<0.001$

AIS: Acute ischemic stroke, ICH: Intracerebral hemorrhage, CVT: Cerebral venous thrombosis 
Although post-stroke seizures have been known for many years, many questions remain unanswered regarding this subject. Furthermore, many studies on this subject have shown different results $(12,13)$. However, the most common cause of seizures seen in older people is stroke. Post-stroke seizure rates in three different studies were reported at $9 \%, 14 \%$, and $19 \%$, respectively. In another study, it was found that $3.2 \%$ of patients followed for seven years after stroke had developed epilepsy $(10,14,15,16,17,18)$. We also investigated the frequency of early seizures and affecting factors in patients with AIS, ICH, and SVT in our neurology ICU. Of the patients followed up within the defined period, $19.5 \%$ of those with AIS, $20.5 \%$ of patients with ICH, and $100 \%$ of patients with SVT had early seizures; $16.7 \%$ of these seizures were focal (partial) and $83.3 \%$ were generalized. Previous studies have shown different rates for post-stroke early seizures including $35 \%, 48 \%$, and $54 \%(10,19,20,21)$. In our study, this rate was $24.1 \%$ in patients in the ICU. Patients with AIS and ICH did not differ in terms of post-stroke early seizure incidence; however, all of the patients with SVT followed-up experienced early seizures after stroke; $72.7 \%(n=8)$ of these patients had seizure during admission. Additionally, the mean duration of seizures in patients with SVT was shorter than in those patients with AIS and $\mathrm{ICH}$. This suggests seizure presence in patients with SVT is an indication for follow-up in the ICU. Bladin et al. (22) found that $\mathrm{ICH}$ was an independent risk factor for post-stroke seizure in their study conducted on large number of patients. The different results found in our study may be due to the smaller number of patients. Kammersgaard and Olsen (15) found that being young carried a risk for the development of seizures after stroke. In some studies conducted in this regard, age was found not to be an independent risk factor in post-stroke seizure $(10,23)$. In our study, we also found no differences in patients' age with respect to those with and without post-stroke early seizures. Different results have also been obtained in studies that investigated whether sex was a risk factor in the development of seizures after ischemia $(10,15,20,23)$. In our study, we found that sex was not effective in the development of early seizures after ischemia.

In studies that investigated risk factors for post-stroke seizures, the best-known risk factor for early seizures after AIS was cortical involvement $(10,22)$. In our study, we found that cortical involvement in patients with AIS and ICH had a significant effect on early seizure formation.

In our study, we found that if hemorrhagic transformation was present in patients with AIS, the rate of early seizure was higher in this patient group compared with the non-hemorrhagic group. Previous studies found cardioembolic events as the cause of this and the increased risk of post-stroke seizure in patients with AIS $(22,24,25)$. If cardioembolic infarcts are thought to have a high risk of hemorrhagic transformation, our findings may be related to this.

Another result of our study was that the lesion volume was significantly larger in patients with AIS who had early seizures relative to patients with AIS who had no seizures. However, there was no relationship between the presence of early seizure and lesion size in patients with ICH. In a study conducted by Bladin et al., (22) it was found that the lesion size was an independent risk factor for AIS without experiencing post-stroke seizures, consistent with our study, whereas there was no correlation between lesion size and seizure in ICH. The cause of early seizures after AIS is thought to be the formation of an electrically irritable tissue as a result of cellular biochemical dysfunction. It is thought that the increase of extracellular glutamate is also effective in this. It has been observed that depolarization of the area surrounding the infarct increases. There is also a relationship between infarct volume in the ischemic area and the severity and number of depolarizing events. These findings in the literature are consistent with the results of our study in which we found that infarct volume increased the rate of early seizure development in patients with AIS $(13,26,27,28)$. The mechanisms leading to early seizure in $\mathrm{ICH}$ have not yet been elucidated (22).

One of the interesting findings of our study was that patients with left hemisphere lesions had a higher risk of developing early seizures compared with patients with right hemisphere lesions. We found no information in the related literature regarding whether the hemispheric variable increased the risk of post-stroke seizures. The reason for this may be due to the pathophysiologic mechanisms leading to early seizures after ischemia. In other words, cellular biochemical dysfunction may facilitate different biochemical and histologic contents of the left hemisphere. For example, in a study, the amount of iron in the left hemisphere was found to be

Table 5. Comparison of National Institutes of Health Stroke Scale and lesion volume values based on early seizure in patients with AIS and ICH

\begin{tabular}{|c|c|c|c|c|}
\hline \multirow[b]{2}{*}{ Variables } & \multicolumn{2}{|c|}{ Early seizure } & \multicolumn{2}{|c|}{ Test statistic } \\
\hline & $\begin{array}{c}\text { Present } \\
\text { Mean } \pm \text { SD Median }(I Q R)\end{array}$ & $\begin{array}{c}\text { Absent } \\
\text { Mean } \pm \text { SD Median }(I Q R)\end{array}$ & $\mathrm{Z}$ & $\mathrm{p}$ \\
\hline NIHSS (AIS) & $\begin{array}{c}17.89 \pm 9.10 \\
16.00(19.50)\end{array}$ & $\begin{array}{c}20.43 \pm 8.47 \\
23.00(13.00)\end{array}$ & 1.200 & 0.230 \\
\hline Lesion volume (AIS) & $\begin{array}{l}102.60 \pm 104.89 \\
70.38(150.74)\end{array}$ & $\begin{array}{l}75.24 \pm 112.52 \\
25.31(99.55)\end{array}$ & 2.116 & 0.034 \\
\hline NIHSS (ICH) & $\begin{array}{c}22.75 \pm 8.56 \\
28.00(16.50)\end{array}$ & $\begin{array}{c}23.87 \pm 8.48 \\
25.00(11.00)\end{array}$ & 0.192 & 0.848 \\
\hline Lesion volume (ICH) & $\begin{array}{l}49.65 \pm 43.02 \\
37.85(66.20)\end{array}$ & $\begin{array}{l}48.70 \pm 63.54 \\
33.45(52.44)\end{array}$ & 0.417 & 0.676 \\
\hline
\end{tabular}


higher than in the right hemisphere, which was thought to lead to more oxidative stress and mitochondrial dysfunction in the left hemisphere (29).

One of the findings of our study was that $54.5 \%(n=6)$ of patients with SVT had lesions in the superior sagittal sinus. This is consistent with the study conducted by Jacobs et al. (30). In their study, the superior sagittal sinus and cortical venous thrombosis, which provides venous drainage from the motor and sensorial cortex, were found to be a risk for seizures in SVT.

The retrospective nature of our research and the lack of electroencephalography records are limitations to our study. However, our study is important and valuable because it is the first study to evaluate patients with AIS, ICH and SVT who were followed up in the ICU and had early seizures.

\section{Ethics}

Ethics Committee Approval: Retrospective study.

Informed Consent: Retrospective study.

Peer-review: Externally peer-reviewed.

\section{Authorship Contributions}

Surgical and Medical Practices: Ş.G., G.V., Concept: Ş.G., G.V., Design: Ş.G., Data Collection or Processing: Ş.G., G.V., Analysis or Interpretation: Ş.G., G.V., Literature Search: G.V., Writing: Ş.G., G.V.

Conflict of Interest: No conflict of interest was declared by the authors.

Financial Disclosure: The authors declared that this study received no financial support.

\section{References}

1. Cerebrovascular disorders. A clinical and research classification. Geneva: WHO 1978. Available from: http://apps.who.int/iris/bitstream/10665/37194/1/ WHO_OFFSET_43.pdf

2. Balkan S. Serebrovasküler Hastalıklar. Güneş Kitabevi Yayınları 2002;5:49.

3. Hashmi M, Wasay M. Caring for cerebral venous sinus thrombosis in children. J Emerg Trauma Shock 2011;4:389-394.

4. Silverman IE, Restrepo L, Mathews GC. Poststroke seizures. Arch Neurol 2002;59:195-201

5. Balami JS, Chen RL, Grunwald IQ, Buchan AM. Neurological complications of acute ischemic stroke. Lancet Neurol 2011;10:357-371.

6. Balami JS, Buchan AM. Complications of intracerebral haemorrhage. Lancet Neurol 2012;11:101-118.

7. Kutlu G, Gomceli YB, Unal Y, Inan LE. Levetiracetam monotherapy for late poststroke seizures in the elderly. Epilepsy Behav 2008;13:542-544.

8. Shinton RA, Gill JS, Melnick SC, Gupta AK, Beevers DG. The frequency, characteristics and prognosis of epileptic seizures at the onset of stroke. J Neurol Neurosurg Psychiatry 1988;51:273-276.

9. Conrad J, Pawlowski M, Dogan M, Kovac S, Ritter MA, Evers S. Seizures after cerebrovascular events: risk factors and clinical features. Seizure $2013 ; 22: 275-282$
10. Göksu EÖ, Genç F, Yüksel B, Gencer ES, Erdal A, Gömceli YB. İnme Sonrası Epilepside Nöbetlerin Klinik Özellikleri, Prognoz ve Tedavisi Epilepsi 2015;21:111-118.

11. Ferro JM, Correia M, Rosas MJ, Pinto AN, Neves G; Cerebral Venous Thrombosis Portuguese Collaborative Study Group[Venoport]. Seizures in cerebral vein and dural sinus thrombosis. Cerebrovasc Dis 2003;15:78-83.

12. Bann HJ. Ischemia and lesion induced imbalances in cortical function. Prog Neurobiol 1996;48:131-166.

13. Heiss WD, Huber M, Fink GR, Herholz K, Pietrzyk U, Wagner R, Wienhard $\mathrm{K}$. Progressive derangement of periinfarct viable tissue in ischemic stroke. J Cereb Blood Flow Metab 1992;12:193-203.

14. Wang G, Jia H, Chen C, Lang S, Liu X, Xia C, Sun Y, Zhang J. Analysis of risk factors for first seizure after stroke in Chinese patients. Biomed Res Int 2013;2013:702871.

15. Kammersgaard LP, Olsen TS. Poststroke epilepsy in the Copenhagen stroke study: incidence and predictors. J Stroke Cerebrovasc Dis 2005;14:210-214.

16. Butzkueven H, Evans AH, Pitman A, Leopold C, Jolley DJ, Kaye AH, Kilpatrick CJ, Davis SM. Onset seizures independently predict poor outcome after subarachnoid hemorrhage. Neurology 2000;55:1315-1320.

17. Sung CY, Chu NS. Epileptic seizures in intracerebral haemorrhage. J Neurol Neurosurg Psychiatry 1989;52:1273-1276.

18. Pinto AN, Canhao P, Ferro JM. Seizures at the onset of subarachnoid haemorrhage. J Neurol 1996;243:161-164.

19. Berges S, Moulin T, Berger E, Tatu L, Sablot D, Challier B, Rumbach R. Seizures and epilepsy following strokes: recurrence factors. Eur Neurol 2000;43:3-8.

20. Demir T, Aslan K, Balal M, Bozdemir H. Clinical features of poststroke epilepsy and relationship with prognosis. Epilepsi 2013;19:121-126.

21. Sıvacı AÖ, Örün MO, Demir AB, Bora İ. Correlation between lesion location and EEG findings in poststroke Epilepsy. Epilepsi 2015;21:20-24.

22. Bladin CF, Alexandrov AV, Bellavance A, Bornstein N, Chambers B, Coté R, Lebrun L, Pirisi A, Norris JW. Seizures after stroke: a prospective multicenter study. Arch Neurol 2000;57:1617-1622.

23. Burneo JG, Fang J, Saposnik G; Investigators of the Registry of the Canadian Stroke Network. Impact of seizures on morbidity and mortality after stroke: a Canadian multi-centre cohort study. Eur J Neurol 2010;17:52-58.

24. Kilpatrick CJ, Davis SM, Tress BM, Rossiter SC, Hopper JL, Vandendriesen ML. Epileptic seizures in acute stroke. Arch Neurol 1990;47:157-160.

25. Dávalos A, de Cendra E, Molins A, Ferrandiz M, Lopez-Pousa S, Genís D. Epileptic Seizures at the Onset of Stroke. Cerebrovasc Dis 1992;2:327-331.

26. Luhmann HJ. Ischemia and lesion induced imbalances in cortical function. Prog Neurobiol 1996;48:131-166.

27. Sun DA, Sombati S, DeLorenzo RJ. Glutamate injury-induced epileptogenesis in hippocampal neurons: an in vitro model of stroke-induced "epilepsy." Stroke 2001;32:2344-2350.

28. Back T, Ginsberg MD, Dietrich WD, Watson BD. Induction of spreading depression in the ischemic hemisphere following experimental middle cerebral artery occlusion: effect on infarct morphology. J Cereb Blood Flow Metab 1996;16:202-213.

29. Langkammer C, Krebs N, Goessler W, Scheurer E, Ebner F, Yen K, Fazekas F, Ropele S. Quantitative MR imaging of brain iron: a postmortem validation study. Radiology 2010;257:455-462.

30. Jacobs K, Moulin T, Bogousslavsky J, Woimant F, Dehaene I, Tatu L, Besson $\mathrm{G}$, Assouline E, Casselman J. The stroke syndrome of cortical vein thrombosis. Neurology 1996;47:376-382. 